\title{
Jaarverslaggeving door onderwijsinstellingen: effect eerste RJ 660
}

\section{Koos Vos, Jos Blommaert en Johan Berkouwer}

SAMENVATTING De inmiddels aangepaste Regeling jaarverslaggeving onderwijs en de Richtlijn 660 Onderwijsinstellingen zijn vanaf het verslagjaar 2008 ingevoerd. Richtlijn 660 is bedoeld om te komen tot een meer actuele en geharmoniseerde jaarverslaggeving voor de gehele onderwijssector. Belangrijk is de onderlinge vergelijkbaarheid tussen de onderwijsinstellingen.

Na een algemene beschrijving van het kader van de regelgeving en de onduidelijkheid over de openbaarmaking, komen in deze bijdrage onderdelen van de horizontale verantwoording aan de orde. De gegevensverstrekking in de soorten bestuursverslag, onder andere gericht op resultaatanalyse en interne beheersing behoeft verbetering. Behalve in gewenst beter gebruik van de jaarrekening-modellen en segmentatie, wordt ook inzicht gegeven in de eenmalige stelselwijziging als gevolg van de nieuwe RJ 660. Tot slot wordt ingegaan op de verbeterimogelijkheden van de belangrijkste balansposten voor de financiële positie. Hierbij wordt ook stilgestaan bij het spanningsveld qua inzicht tussen RJ 271 (Personeelsbeloningen) en de verwerking van de BAPOvoorziening in de jaarrekening.

RELEVANTIE VOOR DE PRAKTIJK De afgelopen jaren zijn verschaffers, zoals bestuurders en controllers, accountants en de minister van Onderwijs als gebruikers druk bezig geweest met de verslaggeving van een van de grote onderdelen van de publieke sector: de onderwijssector. Belangrijke bevindingen over de gegevensverstrekking 2008 naar aanleiding van de eerste Richtlijn 660 komen aan de orde in deze bijdrage. Het streven is naar een meer uniforme en transparantere jaarverslaggeving.

\section{Inleiding}

Onderwijsinstellingen zijn maatschappelijke organisaties zonder winstoogmerk (OZW), die ook naar continuïteit streven en die als rechtspersonen met een wettelijke taak (RWT; art. 91 lid 1 sub d Comptabiliteitswet 2001) actief zijn in het geven van onderwijs aan personen. Deze onderwijsinstellingen, zoals omschreven in artikel 1 sub a Regeling jaarverslaggeving onderwijs (Rjo; OCW, 2007), zijn alle door het ministerie van Onderwijs, Cultuur en
Wetenschap (OCW) en het ministerie van Landbouw, Natuur en Voedselkwaliteit (LNV) op grond van de onderwijswetgeving bekostigde universiteiten, hogescholen, regionale opleidingencentra (ROC's), agrarische opleidingencentra (AOC's), kenniscentra voor beroepsonderwijs, instellingen voor vakonderwijs, scholen voor voortgezet onderwijs, scholen voor primair onderwijs, scholen voor speciaal onderwijs en expertisecentra. Deze instellingen zijn onder te verdelen in de volgende sectoren:

- hoger onderwijs (HO) bestaande uit wetenschappelijk onderwijs (WO) en hoger beroepsonderwijs (HBO);

- middelbaar beroepsonderwijs (MBO)룰

- voortgezet onderwijs (VO);

- primair onderwijs (PO).

Een algemeen overzicht van enkele relevante kenmerken van de onderwijssector wordt gegeven in tabel 1.

\section{Tabel 1 Relevante kenmerken van de onderwijssector 2008}

\begin{tabular}{|l|c|c|c|}
\hline Sector: & $\begin{array}{l}\text { Aantal } \\
\text { instellingen }\end{array}$ & $\begin{array}{l}\text { Aantal } \\
\text { besturen }\end{array}$ & $\begin{array}{l}\text { Totale uitgaven } \\
\text { OCW (x € 1 mln.) }\end{array}$ \\
\hline WO & 14 & 14 & 3.677 \\
\hline HBO & 36 & 34 & 2.159 \\
\hline MBO & 60 & 40 & 3.345 \\
\hline VO & 647 & 308 & 6.485 \\
\hline PO & 7.534 & 1.284 & 8.981 \\
\hline Totaal: & 8.291 & 1.680 & 24.647 \\
\hline
\end{tabular}

Bron: Kerncijfers 2004 - 2008 OCW

Uit tabel 1 blijkt dat, in het bijzonder in het po en vo, een rechtspersoon ${ }^{2}$ mede door bestuurlijke fusies meerdere (soorten) onderwijsinstellingen (art.1 sub a Rjo) in stand kan houden. Het jaarverslag wordt in het po en vo opgesteld per rechtspersoon. Gezien de wettelijke bepalingen is 
dit in de andere sectoren per onderwijsinstelling (art. 3 sub h en p. 10 Rjo). Dit heeft gevolgen voor de consolidatie en segmentatie, waarop in paragraaf 5.4 nader zal worden ingegaan. Ieder van deze rechtspersonen of instellingen maakt een jaarverslag (art. 2:10 lid 2 BW), op basis van de inrichtingseisen en grondslagen van de Regeling jaarverslaggeving onderwijs (Rjo). Onder andere het jaarverslag of de jaarverslaggeving (art. 1 sub c Rjo) dient jaarlijks voor 1 juli te worden aangeleverd bij de Centrale Financiën Instellingen (CFI), agentschap van OCW (art. 4 lid 1 Rjo; RJ 660.607).

De onderwijsinstellingen vallen gezien hun doelstelling en aard van inkomsten onder de non-profitorganisaties. De primaire functie van non-profitorganisaties bestaat meestal uit het tot stand brengen van maatschappelijk gewenste voorzieningen. De financiële middelen om deze voorzieningen te kunnen verwezenlijken, krijgen de organisaties veelal geheel of gedeeltelijk uit gemeenschapsgelden (Aukes, 1996, p. 26). Binnen de non-profit sector wordt eveneens de term 'organisaties zonder winstoogmerk' (OZW's) gehanteerd: 'Een OZW is een organisatie waarvan de doelstelling gelegen is in het leveren van bepaalde goederen of diensten teneinde een zeker maatschappelijk nut te creëren, waarbij de financiering van activiteiten en de financiële positie randvoorwaarden vormen' (Herremans et al., 2003, p. 17).

De Regeling jaarverslaggeving onderwijs (Rjo) en de Richtlijn 660 Onderwijsinstellingen (RJ 660) zijn eind 2007 gepubliceerd. De Rjo is begin 2009 door de minister van Onderwijs aangepast (OCW, 20ogb), waarop in paragraaf 6.5 nader zal worden ingegaan. Ze vormen de nieuwe verslaggevingbasis, de eerste keer voor het jaarverslag 2008, van de onderwijsinstellingen. In dit artikel wordt een inventariserende beschouwing gegeven over de gegevensverstrekking in relatie tot deze invoering en harmonisering die hiermee gerealiseerd wordt in de onderwijssector. Eerst wordt in paragraaf 2 ingegaan op het algemeen kader van wet- en regelgeving. In paragraaf 3 komen de onduidelijkheid op het gebied van het openbaar maken van jaarverslagen en de selectie van de onderzochte jaarverslagen aan de orde.

Vervolgens wordt ingegaan op enkele in het kader van harmonisatie belangrijke onderwerpen, die ook bepalend zijn voor de eigenheid (zie ook Dees et al., 2009, par. 2.2) van de onderwijssector. In paragraaf 4 wordt aandacht besteed aan de rol van het bestuursverslag en enkele daarin opgenomen onderwerpen voor de horizontale verantwoording. In de volgende paragraaf komen enkele onderwerpen aan de orde die relevant zijn voor de jaarrekening in het jaar van de eerste toepassing van RJ 660. In paragraaf 6 wordt ingegaan op balansposten die belangrijk zijn voor de financiële positie van de instelling, zoals ook recent bleek uit het rapport (OCW, 2009c) van de Commissie Don aan de Tweede Kamer over het vermogensbeheer van de instel- lingen. Tot slot volgen in paragraaf 7 enkele conclusies voor de verslaggevingspraktijk.

\section{Algemeen kader van wet- en regelgeving}

Op basis van de ministeriële Regeling jaarverslaggeving onderwijs (Rjo) is Titel 9 Boek 2 BW van overeenkomstige toepassing (art. 2 Rjo en RJ 660.101) op de jaarverslaggeving van onderwijsinstellingen. In afwijking hiervan of in aanvulling hierop wordt de jaarverslaggeving ingericht overeenkomstig de Richtlijnen voor de jaarverslaggeving zoals die zijn vastgesteld door de Raad voor de Jaarverslaggeving, in het bijzonder de hoofdstukken 40o, 640 en 660 (art. 3 sub a Rjo). Voor iedere onderwijssector wordt de juridische grondslag voor de Rjo gevonden in afzonderlijke sectorale besluiten en wetten (zie Rjo, p. 1). Ook uit deze grondslag blijkt de diversiteit en complexe juridische structuur van het onderwijs.

Vóór de Rjo golden voor de vier verschillende onderwijssectoren afzonderlijke jaarverslaggevingsrichtlijnen van OCW (art. 5 Rjo), die voor een belangrijk deel historisch waren bepaald. Die OCW-richtlijnen waren gekoppeld aan de sectorale en gefaseerde invoering van de normatieve bekostiging (lump sum) en de wijze van overdracht van de oorspronkelijke onderwijsgebouwen van OCW. Door deze fasering zijn er op het punt van het jaarverslag gaandeweg aanmerkelijke verschillen ontstaan tussen de verschillende onderwijssectoren. Afgezien van het steeds zwaarder voelen van de onvergelijkbaarheid van gegevens, is ook sprake van groeiende samenwerking en integratie van verschillende onderwijssectoren binnen de besturen. Bij die ontwikkeling past alleen een geharmoniseerde jaarverslaggeving met één Rjo (zie ook Dees et al., 2009, par. 2.7). Een andere belangrijke reden voor de Rjo ligt in de dynamische en vakinhoudelijke ontwikkelingen op het terrein van de jaarverslaggeving. Het is vanzelfsprekend dat ook onderwijsinstellingen bij deze ontwikkelingen niet mogen achterblijven. Als voorbeelden gelden de grondslagen voor de waardering van activa, de componentenindeling bij vaste activa (zie ook par. 6.2), het omgaan met reserves en voorzieningen, de consolidatiebepalingen en de bijzondere baten en lasten. In de door OCW opgestelde was-wordttabel (OCW, 2008, p. 67-74) worden de belangrijkste wijzigingen opgenomen van de RJ ten opzichte van de oude OCW-richtlijnen. Voor publieke instellingen is als speerpunt van het beleid gekozen voor het stimuleren van de zogenoemde horizontale verantwoording naast de verticale verantwoording aan de minister. Onder horizontale verantwoording wordt verstaan de communicatie met de directe betrokkenen over de wijze waarop de instelling uitvoering geeft aan haar maatschappelijke taak en hoe zij daartoe de aan haar beschikbaar gestelde middelen heeft ingezet. Om deze discussie goed te kunnen vormgeven is het van belang dat de betrokken partijen beschikken over 
vergelijkbare en relevante financiële en niet-financiële informatie (o.a. RJ 400) op basis van een uniforme wijze van verwerken, waarderen en presenteren van informatie door verschillende soorten onderwijsinstellingen. Deze Rjo biedt evenwicht tussen deze soorten informatie, maar laat daarbij de invulling van het niveau waarop in het bijzonder de niet-financiële informatie aan gebruikers wordt verstrekt voor een belangrijk deel over aan afspraken tussen de betrokkenen zelf (Rjo, 2007, p. 5-6).

\section{Openbaarheid en de selectie van de onderzochte jaarverslagen}

Onderwijsinstellingen lijken hun jaarverslag niet actief openbaar te maken op bijvoorbeeld hun website. ${ }^{3}$ In RJ 640.603 wordt dit wel aanbevolen. Het ministerie en de wetgever zijn in het belang van openbaar maken echter niet eenduidig, zoals blijkt uit de volgende deels tegenstrijdige bronnen:

- 'het instellingsbestuur dient jaarlijks voor 1 juli bij onze minister een verslag in' (art. 2.9 lid 1 Wet op het Hoger onderwijs en Wetenschappelijk onderzoek). Dit lijkt meer op interne verticale verantwoording en niet op horizontale verantwoording aan alle belanghebbenden;

- de controle van de jaarrekening van een onderwijsinstelling 4 is geen wettelijke controle als bedoeld in artikel 1 lid sub $\mathrm{p}$ Wet toezicht accountantsorganisaties (Wta), waarmee de jaarrekening niet bedoeld lijkt voor het maatschappelijk verkeer, hoewel Titel 9 Boek 2 BW wel van overeenkomstig toepassing is (art. 2 Rjo);

- in artikel 2 Rjo wordt Titel 9 Boek 2 BW afdeling 10 Openbaarmaking, niet uitgezonderd (zie ook RJ 640.602);

- onduidelijk is of alleen de financiële jaarverslaggeving openbaar gemaakt moet worden (RJ 660.607) of de totale jaarverslaggeving (art. 4 lid 1 Rjo);

- 'Overigens verspreidt OCW/CFI de jaarverslagen niet zonder meer aan iedereen die daarom verzoekt. Voor een exemplaar van een geheel jaarverslag wordt doorverwezen naar de instelling zelf (OCW, 2008, p. 14).

Eind juni 2009 was de uiterste aanleverdatum voor alle jaarverslagen over 2008 van de onderwijsbesturen. De CFI heeft aangegeven dat er begin juli een verwerkingstijd is van ongeveer twee weken. Daarna worden de jaarverslagen op de dag van binnenkomst direct verwerkt. De selectie van de besturen heeft begin augustus plaatsgevonden uit een bestand van alle instellingen en besturen per 1 augustus 2009. In de selectie zijn honderd besturen of rechtspersonen betrokken, waarbij alle universiteiten (100 procent) en ruim twintig rechtspersonen uit ieder van de andere sectoren random getrokken zijn, wat voor het PO uitkomt op ruim één procent van de rechtspersonen. Op basis van deze (niet homogene) instellingen en hun jaar- verslagen per sector kunnen per sector indicatieve uitspraken gedaan worden en kunnen de sectoren onderling worden vergeleken. Een maand na de uiterste aanleverdatum van 30 juni blijkt dat vier (4 procent) van de getrokken besturen het jaarverslag 2008 nog niet bij de CFI hebben aangeleverd (zie tabel 2). De namen van de honderd besturen en de 96 in het onderzoek betrokken jaarverslagen zijn opgenomen in de bijlage. Bij het beoordelen van de 96 jaarverslagen 2008 hebben wij gebruik mogen maken van bij de CFI elektronisch ontsloten bron van jaarverslagen. Gezien het totale aantal van 96 jaarverslagen en de presentatie van de resultaten van de circa twintig jaarverslagen per sector, heeft het niet betrekken van de vier nog niet ontvangen jaarverslagen geen effect op de indicatieve uitspraken.

\section{Tabel 2 Aantal uit steekproef bij CFI aangeleverde jaar- verslagen per 1 augustus 2009}

\begin{tabular}{|c|c|c|c|c|}
\hline \multirow{2}{*}{$\frac{\text { Sector: }}{\text { WO }}$} & \multirow{2}{*}{$\begin{array}{l}\begin{array}{l}\text { Totaal aantal } \\
\text { besturen en } \\
\text { instellingen in } \\
\text { populatie }^{5}\end{array} \\
14\end{array}$} & \multirow{2}{*}{$\begin{array}{l}\begin{array}{l}\text { Aantal } \\
\text { besturen } \\
\text { in steekproef }\end{array} \\
14\end{array}$} & \multicolumn{2}{|c|}{$\begin{array}{l}\text { Jaarverslagen } \\
2008 \text { in steekproef } \\
\text { (aantal en als } \\
\text { percentage van } \\
\text { het aantal } \\
\text { besturen in de } \\
\text { steekproef) }\end{array}$} \\
\hline & & & 14 & 100\% \\
\hline HBO & 39 & 22 & 22 & 100\% \\
\hline MBO & 82 & 22 & 22 & 100\% \\
\hline VO & 308 & 21 & 20 & $95 \%$ \\
\hline PO & 1.432 & 21 & 18 & $86 \%$ \\
\hline Totaal: & 1.875 & 100 & 96 & $96 \%$ \\
\hline
\end{tabular}

De resultaten van het onderzoek naar de jaarverslagen van de 96 onderwijsinstellingen in de onderzoekspopulatie worden hierna weergegeven. In de onderzoekspopulatie zijn 73 ( 76 procent) van de rechtspersonen een stichting en tien (1o procent) verenigingen. In het WO is sprake van één (top)vereniging, twee stichtingen en elf (12 procent) publiekrechtelijke rechtspersonen. In het $\mathrm{PO} / \mathrm{VO}$ zijn twee ( 2 procent) instellingen als openbare school een onderdeel van een gemeente (zie ook art. 3 sub i Rjo).

\section{Het bestuursverslag en horizontale verantwoording}

In deze paragraaf wordt eerst ingegaan op het belang van het bestuursverslag bij het vormgeven van horizontale verantwoording en de mate waarin verschillende soorten bestuursverslagen zijn opgenomen in een jaarverslag. Vervolgens wordt ingegaan op de gegevensverstrekking over resultaten, kengetallen en interne beheersing. 


\subsection{Het belang van het bestuursverslag}

Aan het bestuursverslag van een OZW komt een bijzondere betekenis toe. De aard van de activiteiten van een OZW brengt namelijk met zich mee, dat de maatschappelijke betekenis van die activiteiten slechts beperkt uit de jaarrekening blijkt (RJ 640.501). Het beleid van het ministerie met betrekking tot horizontale verantwoording sluit hier op aan.

De overheid geeft aan een terughoudend beleid te voeren waar het gaat om het stellen van eisen aan het afleggen van verantwoording van instellingen richting het ministerie. Het ministerie gebruikt jaarcijfers en jaarverslagen vooral voor de uitvoering van haar toezicht- en evaluatietaken. De verantwoording over het gevoerde beleid, over de gang van zaken binnen de instelling, over de behaalde resultaten en de inzet van middelen moet met name ook geschieden richting de interne en externe belanghebbenden. De horizontale verantwoording bestaat uit het verstrekken van informatie, het voeren van discussies en het maken van afspraken. Deze discussie met de omgeving kan uiteraard alleen goed worden gevoerd als de gesprekspartners beschikken over tijdige en transparante gegevens. Daarbij kan het jaarverslag een cruciale rol spelen. Daarom wordt van het bestuur verwacht dat zij het jaarverslag zodanig inricht dat dit een volledig beeld schetst, relevante informatie bevat die voldoende is gesegmenteerd naar opleidingen en/of vestigingen en gericht op de behoeften van de gebruikers, tijdig beschikbaar komt en vlot toegankelijk is (OCW, 2008, p. 18). Belangrijk is dat het bestuur in het bestuursverslag melding maakt van de wijze waarop zij de horizontale verantwoording met de omgeving vormgeeft en hoe zij omgaat met de resultaten daarvan (RJ 400.119 $\mathrm{t} / \mathrm{m} 125 \mathrm{en} \mathrm{RJ} \mathrm{660.407).}$

\subsection{Het opnemen van soorten bestuursverslagen}

Op basis van artikel 2 Rjo en RJ 660.4 is het verplicht om een bestuursverslag op te nemen. Daarnaast is in artikel 3 sub e van de Rjo opgenomen dat het jaarverslag moet worden uitgebreid met een verslag van de interne toezichthouder (indien aanwezig). In de praktijk kan men, mede afhankelijk van het bestuursmodel, 'drie soorten bestuursverslagen' aantreffen: het verslag Raad van Toezicht (dit kan privaatrechtelijk ook formeel het bestuur zijn; naast de RvT een $\mathrm{CvB}$ ), het bestuursverslag (van bijvoorbeeld het College van Bestuur of het gewone stichtingsbestuur, over de bestuursvergaderingen of geschreven door de directie over de gang van zaken) en een directieverslag (van het uitvoerend orgaan bijvoorbeeld een rector of vestigingsdirecteur).

Tijdens het onderzoek valt op dat het jaarverslag veelal niet één document is en dat veelal een publieksversie van het (bestuurs)jaarverslag wordt aangeleverd met daarbij een losse jaarrekening. Uit de tabellen 3 en 4 blijkt verder in welke mate aan de voorschriften wordt voldaan in de situatie van een 'Raad van Toezicht'-model (vaak RvT en CvB; tabel 3) of alleen 'Bestuur'-model (vaak bestuur en directie; tabel 4).

\section{Tabel 3 Aantal verslagen van bestuur en toezichthouder bij 'Raad van Toezicht'-model}

\begin{tabular}{|c|r|r|r|c|c|}
\hline Sector: & n: & \multicolumn{2}{|l|}{$\begin{array}{l}\text { Verslag bestuur } \\
\text { opgenomen }\end{array}$} & \multicolumn{2}{|c|}{$\begin{array}{l}\text { Verslag toezichthouder } \\
\text { opgenomen }\end{array}$} \\
\hline WO & 14 & 14 & $100 \%$ & 14 & $100 \%$ \\
\hline HBO & 22 & 20 & $91 \%$ & 18 & $82 \%$ \\
\hline MBO & 22 & 22 & $100 \%$ & 11 & $50 \%$ \\
\hline V0 & 6 & 6 & $100 \%$ & 2 & $33 \%$ \\
\hline P0 & 2 & 2 & $100 \%$ & 0 & $0 \%$ \\
\hline Totaal: & 66 & 64 & $97 \%$ & 45 & $68 \%$ \\
\hline
\end{tabular}

Bij de sectoren die volledig zijn overgegaan op een 'Raad van Toezicht'-model wordt bijna altijd een verslag van het bestuur (vaak CvB) toegevoegd. Bij twee hbo-instellingen is geen enkel verslag opgenomen. Een afzonderlijk verslag van de Raad van Toezicht komt niet overal voor (68 procent), hoewel dit wel verplicht is (art. 3 sub e Rjo).

\section{Tabel 4 Aantal verslagen van directie en bestuur bij 'Bestuur'-model}

\begin{tabular}{|c|l|c|c|c|c|}
\hline Sector: & \multicolumn{3}{|c|}{ Verslag directie } & \multicolumn{2}{c|}{$\begin{array}{l}\text { Verslag bestuur } \\
\text { opgenomen }\end{array}$} \\
\hline VO & 14 & 7 & $50 \%$ & 12 & $86 \%$ \\
\hline PO & 16 & 2 & $13 \%$ & 14 & $88 \%$ \\
\hline Totaal: & 30 & 9 & $30 \%$ & 26 & $87 \%$ \\
\hline
\end{tabular}

Het 'Bestuur'-model komt eigenlijk alleen voor bij po/vobesturen. Bij vijf vo-instellingen komt zowel een bestuurs- als directieverslag voor. Zeven vo-instellingen, zonder een directieverslag, hebben wel een verslag van het bestuur. Alle po-instellingen hebben één van beide verslagen opgenomen.

\subsection{Resultaatanalyse en het gebruik van kengetallen}

Wat betreft de inhoud van de bestuursverslagen hebben 89 (93\%) van de onderzochte instellingen in hun bestuursverslag een analyse van het resultaat (RJ 660.401; RJ 400.109) over 2008 opgenomen. Van deze 89 instellingen hebben 87 deze analyse gebaseerd op de begroting. Bij de beoordeling van het resultaat is, naast de wijze van verantwoorden (RJ 660.301/303), het aandeel en de grondslag van de rijksbijdrage bepalend; zie tabel 5 . 
Tabel 5 Aandeel rijksbijdrage van de baten (2007) per sector

\begin{tabular}{|l|l|l|l|}
\hline Sector: & $\begin{array}{l}\text { Rijkshijdrage als percentage van } \\
\text { de baten }\end{array}$ & $\begin{array}{l}\text { Overige bijdragen als } \\
\text { percentage van de baten }\end{array}$ & Bekostigingsgrondslag lumpsum \\
\hline WO & $65,0 \%$ & $35,0 \%$ & Aantal inschrijvingen en graadverleningen (incl. promoties) \\
\hline HBO & $67,9 \%$ & $32,1 \%$ & Aantal inschrijvingen en graadverleningen \\
\hline MBO & $80,3 \%$ & $19,7 \%$ & Aantal studenten en behaalde diploma's \\
\hline VO & $92,1 \%$ & $7,9 \%$ & Aantal leerlingen per opleidingsniveau \\
\hline PO & $90,1 \%$ & $9,9 \%$ & Aantal leerlingen per leeftijdscategorie en leeftijd docenten \\
\hline
\end{tabular}

Bron: Kernciffers 2004 - 2008 OCW

Bij de beoordeling van het resultaat is van belang zich te realiseren dat indien het leerlingaantal toeneemt, dit in dat jaar, onder overigens gelijkblijvende omstandigheden, zal leiden tot een daling van het resultaat en mogelijk een verlies. Dit wordt veroorzaakt door beperkte matching door de ( $t-1)$ systematiek van het bekostigingsmodel, waarbij de toegekende rijksbijdrage (inkomsten jaar t), op basis van bekostigingsaantallen uit eerdere jaren (zie tabel 5), als toegerekende bate (jaar $\mathrm{t}$ ) in de staat van baten en lasten wordt verantwoord (RJ 660.301). De informatie over de bekostiging en de subsidievoorwaarden behoeven echter niet in de toelichting te worden opgenomen (RJ 660.303).

In RJ 430 wordt aanbevolen dat in het bestuursverslag aandacht wordt geschonken aan de financiële positie door middel van kengetallen. In tabel 6 staat aangegeven in hoeverre deze kengetallen, een analyse daarvan en streefwaarden door de onderzochte instellingen in het jaarverslag zijn opgenomen.

\section{Tabel 6 Aantal jaarverslagen waarin kengetallen en een analyse zijn opgenomen}

\begin{tabular}{|c|c|c|c|c|c|c|c|}
\hline \multirow{2}{*}{$\begin{array}{l}\text { Sector: } \\
\text { WO }\end{array}$} & \multirow{2}{*}{$\frac{n:}{14}$} & \multicolumn{2}{|c|}{$\begin{array}{l}\text { Kengetallen } \\
\text { opgenomen }\end{array}$} & \multicolumn{2}{|c|}{$\begin{array}{l}\text { Analyse van } \\
\text { de kengetallen } \\
\text { opgenomen }\end{array}$} & \multicolumn{2}{|c|}{$\begin{array}{l}\text { Streefwaarden } \\
\text { opgenomen }\end{array}$} \\
\hline & & 12 & $86 \%$ & 9 & $64 \%$ & 5 & $36 \%$ \\
\hline HBO & 22 & 20 & $91 \%$ & 17 & $77 \%$ & 9 & $41 \%$ \\
\hline MBO & 22 & 21 & $95 \%$ & 16 & $73 \%$ & 6 & $27 \%$ \\
\hline VO & 20 & 20 & $100 \%$ & 15 & $75 \%$ & 6 & $30 \%$ \\
\hline PO & 18 & 17 & $94 \%$ & 16 & $89 \%$ & 5 & $28 \%$ \\
\hline Totaal: & 96 & 90 & $94 \%$ & 73 & $76 \%$ & 31 & $32 \%$ \\
\hline
\end{tabular}

Dat de sectoren met relatief veel kleine instellingen (vo en po), hoog scoren op het opnemen van kengetallen en een analyse, hangt waarschijnlijk samen met de standaardopzet van de jaarverslagen van de administratiekantoren. Van de onderzochte jaarverslagen bevatten 73 ( 76 procent) kengetallen en een analyse op de mutaties van deze kengetallen. Van de instellingen heeft 32 procent aangegeven welke waarde voor deze getallen wordt nagestreefd. Veelal betrof dit instellingen die de streefwaarden al hadden gerealiseerd. Van deze 31 instellingen hebben dertien aangegeven hoe zij deze willen gaan realiseren. Van de 96 instellingen zijn er geen instellingen die noch een analyse van het resultaat noch kengetallen hebben opgenomen.

\subsection{Verantwoording over interne beheersing}

In RJ 660.406 wordt bepaald dat het bestuur in het bestuursverslag dient te rapporteren over de aanwezigheid van het interne risicobeheersings- en controlesysteem in het boekjaar. Eveneens moeten aangebrachte significante wijzigingen worden gemeld en tevens de verbeteringen die zijn gepland. Daarnaast moet informatie worden opgenomen over hoe dit met het toezichthoudend orgaan is besproken. In de toelichtende brochure bij de richtlijn Jaarverslaggeving Onderwijs geeft OCW aan dat het bestuur, indien zij van mening is dat het interne beheersings- en controlesysteem adequaat is, een in-control statement kan opstellen (OCW, 2008, p. 15).

\section{Tabel 7 Aantal instellingen dat informatie verstrekt over risicobeheersings- en controlesysteem}

\begin{tabular}{|c|c|c|c|c|c|c|c|}
\hline \multirow{2}{*}{$\begin{array}{l}\text { Sector: } \\
\text { WO }\end{array}$} & \multirow{2}{*}{$\frac{n:}{14}$} & \multicolumn{2}{|c|}{$\begin{array}{l}\text { Informatie over } \\
\text { aanwezigheid } \\
\text { en ontwikkeling } \\
\text { van het systeem } \\
\text { opgenomen }\end{array}$} & \multicolumn{2}{|c|}{$\begin{array}{l}\text { Oordeel over } \\
\text { werking } \\
\text { systeem } \\
\text { opgenomen }\end{array}$} & \multicolumn{2}{|c|}{$\begin{array}{l}\text { Waarvan in } \\
\text { de vorm van } \\
\text { 'in-control } \\
\text { statement'? }\end{array}$} \\
\hline & & 5 & $36 \%$ & 1 & $7 \%$ & 0 & $0 \%$ \\
\hline HBO & 22 & 8 & $36 \%$ & 0 & $0 \%$ & 0 & $0 \%$ \\
\hline MBO & 22 & 10 & $45 \%$ & 3 & $14 \%$ & 0 & $0 \%$ \\
\hline VO & 20 & 7 & $35 \%$ & 1 & $5 \%$ & 0 & $0 \%$ \\
\hline PO & 18 & 13 & $72 \%$ & 1 & $6 \%$ & 0 & $0 \%$ \\
\hline Totaal: & 96 & 43 & $45 \%$ & 6 & $6 \%$ & 0 & $0 \%$ \\
\hline
\end{tabular}


In 43 ( 45 procent) van de onderzochte jaarverslagen is informatie opgenomen over de aanwezigheid en ontwikkelingen van het interne risicobeheersings- en controlesysteem en zes instellingen geven een oordeel over de werking van dit systeem. In geen enkel jaarverslag is een in-control statement opgenomen. Ook is in de jaarrekening geen rechtmatigheidsverantwoording opgenomen. Wel wordt in diverse jaarverslagen vermeld dat men bezig is om een systeem op te zetten om tot een dergelijke verklaring te komen. Twee voorbeelden van deze ontwikkelingen zijn hieronder opgenomen.

Van de 43 in tabel 7 genoemde instellingen zijn veel jaarverslagen afkomstig uit de po-sector (30 procent). Dit is te verklaren uit het feit dat deze relatief vaak het jaarverslag door een administratiekantoor laten verzorgen, waar een standaardmodel wordt gebruikt.

Uit het onderzoek is verder gebleken dat diverse instellingen in het $\mathrm{MBO}, \mathrm{HBO}$ en WO de bevestiging bij de jaarrekening aan de accountant (letter of representation) hebben opgenomen in de jaarrekening. Veelal werd vanuit het bestuursverslag hiernaar gerefereerd in termen van incontrol statement of 'verklaring interne beheersing'. Dit betreft echter een bevestiging aan de accountant en niet direct een oordeel van het bestuur over de werking van het interne risicobeheersings- en controlesysteem.

\section{De opzet en inrichting van de jaarrekening}

\subsection{Inleiding}

In het licht van de implementatie in 2008 van de nieuwe regeling en richtlijn is onderzoek gedaan naar een aantal onderwerpen in relatie tot de opzet van de jaarrekening. Hierbij is bij de onderzochte jaarrekeningen gekeken naar het gebruik van de modellen, de stelselwijziging, consolidatie en segmentatie.

\subsection{Gebruik RJ 660 en modellen}

In de jaarverslagen van de onderwijsinstellingen moeten vanaf kalenderjaar 2008 nieuwe richtlijnen voor de jaarverslaggeving (RJ 660) worden toegepast (art. 2 en 3 sub a Rjo). Uit nagenoeg alle onderzochte jaarverslagen 92 (96 procent) blijkt dat men in 2008 is overgegaan op een jaar-

\section{Figuur 1 Best practices informatieverstrekking over risicobeheersings- en controlesysteem}

\section{Implementatie risicomanagement en 'in-control statement'}

In 2008 is door Concerncontrol een aanzet gegeven om het risicomanagement meer in de planning \& controlcyclus te verankeren. In de nota Risicomanagement Universiteit Twente opgesteld in het voorjaar 2008 wordt uiteengezet hoe het bewustwordingsproces ten aanzien van het herkennen van strategische risico's en het implementeren van risicomanagement op gang wordt gebracht en welke doelstellingen daarbij worden nagestreefd. Naast externe redenen om aandacht te schenken aan risicomanagement zoals het voldoen aan wet- en regelgeving en aan de wensen van de toezichthouders en belanghebbenden - horizontale verantwoording - worden interne redenen minstens zo belangrijk geacht. De interne redenen zijn gericht op de veranderingen, verbeteringen en het realiseren van de strategische ambities zoals deze zijn vastgelegd in de strategische visie 'Route 14' en de nadere uitwerking daarvan. Het risicomanagement maakt een geïntegreerd onderdeel uit van het Management controlplan vastgesteld door het College van Bestuur in februari 2009. De eenheden hebben in hun Jaarplan 2009 een eerste identificatie gegeven van de strategische risico's die worden voorzien specifiek voor deze betreffende eenheid. Tevens zijn de getroffen of nog te treffen beheersmaatregelen beschreven. Op basis van gegeven classificaties ten aanzien van kans en impact is een prioritering in de risico's aangebracht waarover met ingang van 2009 op de daartoe vastgestelde momenten van de beleidsinhoudelijke voortgangsrapportages (voorheen budgetrapportages) aan het CvB zal worden gerapporteerd.

Bron: Jaarverslag Universiteit Twente, 2008, p. 104.

\section{Governance}

De wettelijke vereisten rond Governance en de gedragscode van de MBO raad zijn een geïntegreerd onderdeel van de werkwijze van ROC Leiden. Binnen de Raad van Toezicht is een commissie 'Governance' gevormd die vier maal per jaar relevante onderwerpen rond verantwoording en toezicht bespreekt. Ook in 2008 was het interne risicobeheersings- en controlesysteem aanwezig en werkte het naar behoren.

Bron: Jaarrekening ROC Leiden, 2008, p. 9 .

verslag op basis van RJ 660. Uit de overige vier jaarverslagen blijkt echter niet dat deze richtlijnen niet zijn toegepast. Hiervan hebben twee HO-instellingen al in 2007 RJ 660 toegepast.

De voorgeschreven modellen (art. 3 sub $\mathrm{f}$ Rjo; RJ 660.105/310/311; bijlage van RJ 660; OCW, 2008, p. 75-102) voor de balans, de staat van baten en lasten, het kasstroomoverzicht en toelichtingen worden goed toegepast, zo blijkt uit tabel 8. Soms wordt een gedetailleerd model toegepast.

\section{Tabel 8 Instellingen die de voorgeschreven modellen toepassen}

\begin{tabular}{|l|c|c|c|c|c|c|c|}
\hline Sector: & $\mathbf{n}:$ & \multicolumn{2}{|c|}{ Model balans toegepast } & Model staat van baten en lasten toegepast & \multicolumn{2}{|c|}{ Model kasstroomoverzicht toegepast } \\
\hline WO & 14 & 13 & $93 \%$ & 12 & $86 \%$ & 14 & $100 \%$ \\
\hline HBO & 22 & 15 & $68 \%$ & 19 & $86 \%$ & 22 & $100 \%$ \\
\hline MBO & 22 & 22 & $100 \%$ & 21 & $95 \%$ & 20 & $100 \%$ \\
\hline VO & 20 & 20 & $100 \%$ & 20 & $100 \%$ & 18 & $100 \%$ \\
\hline PO & 18 & 18 & $100 \%$ & 13 & $72 \%$ & 96 & $100 \%$ \\
\hline Totaal: & 96 & 88 & $92 \%$ & 85 & $89 \%$ & $900 \%$ \\
\hline
\end{tabular}


Het model van de balans wordt in 88 ( 92 procent) jaarrekeningen toegepast. In het ho zijn soms de toelichtingen niet conform het model en zijn er geen verloopoverzichten opgenomen. In zestien procent van de jaarrekeningen was de balans gedetailleerder, in plaats van dat deze detaillering in de toelichting wordt opgenomen.

De staat van baten en lasten werd in 85 ( 89 procent) jaarrekeningen volgens het model gepresenteerd. In het wo en po worden kostensoorten toegevoegd in de staat van baten en lasten. Dit laatste is niet gewenst, omdat dit de vergelijkbaarheid moeilijk maakt. In het hbo en mbo is de toelichting niet altijd conform het model. Ook de staat van baten en lasten werd in zestien procent van de jaarrekeningen gedetailleerder opgenomen. De uitsplitsing van bijvoorbeeld de overige baten wordt dan niet in de toelichting opgenomen.

\subsection{Stelselwijziging}

Eerder bleek dat nagenoeg alle onderzochte instellingen in 2008 zijn overgegaan op een jaarverslag op basis van RJ 660 . In tabel 9 is aangegeven of de gevolgen van deze nieuwe richtlijn als stelselwijziging (RJ 140) zijn doorgevoerd.

\section{Tabel 9 Aantal jaarverslagen waarin informatie over stelselwijziging is opgenomen}

\begin{tabular}{|c|c|c|c|c|c|c|c|}
\hline \multirow{2}{*}{$\begin{array}{l}\text { Sector: } \\
\text { WO }\end{array}$} & \multirow{2}{*}{$\begin{array}{l}\text { n: } \\
14\end{array}$} & \multicolumn{2}{|c|}{ Melding gemaakt van stelselwijziging } & \multicolumn{2}{|c|}{$\begin{array}{l}\text { Geen melding gemaakt van } \\
\text { stelselwijziging }\end{array}$} & \multicolumn{2}{|c|}{$\begin{array}{l}\text { Noodzakelijkheid stelselwijziging blifkt niet uit } \\
\text { jaarverslag }\end{array}$} \\
\hline & & 10 & $71 \%$ & 1 & $7 \%$ & 3 & $21 \%$ \\
\hline $\mathrm{HBO}$ & 22 & 16 & $73 \%$ & 1 & $5 \%$ & 5 & $23 \%$ \\
\hline MBO & 22 & 17 & $77 \%$ & 0 & $0 \%$ & 5 & $23 \%$ \\
\hline VO & 20 & 17 & $85 \%$ & 0 & $0 \%$ & 3 & $15 \%$ \\
\hline PO & 18 & 16 & $89 \%$ & 2 & $11 \%$ & 0 & $0 \%$ \\
\hline Totaal: & 96 & 76 & $79 \%$ & 4 & $4 \%$ & 16 & $17 \%$ \\
\hline
\end{tabular}

Bij twee instellingen in het ho is de stelselwijziging al in 2007 doorgevoerd. In zestien (17 procent) van de onderzochte jaarverslagen is niet toegelicht of de overgang naar RJ 660 effect heeft op de financiële cijfers. In totaal hebben drie instellingen dit effect direct in het resultaat in plaats van rechtstreeks in het eigen vermogen (RJ 140.208) middels een stelselwijziging verantwoord. Uit een nadere analyse van de jaarverslagen van de 76 ( 79 procent) instellingen waar een stelselwijziging heeft plaats gevonden, blijkt dat de toelichting hierop niet altijd volgens de bepalingen in RJ 140 Stelselwijzigingen is opgenomen. In tabel 10 is aangegeven in hoeverre in de 76 jaarverslagen met een stelselwijziging, het effect op het vermogen en het resultaat is toegelicht en of dit is gespecificeerd naar de individuele posten.

\section{Tabel 10 Toelichting op stelselwijziging}

\begin{tabular}{|c|c|c|c|c|c|c|c|}
\hline \multirow{2}{*}{$\begin{array}{l}\text { Sector: } \\
\text { WO }\end{array}$} & \multirow{2}{*}{ n: } & \multicolumn{2}{|c|}{$\begin{array}{l}\text { Waarvan effect op vermogen } \\
\text { toegelicht }\end{array}$} & \multicolumn{2}{|c|}{$\begin{array}{l}\text { Waarvan effect op het resultaat } \\
\text { toegelicht }\end{array}$} & \multicolumn{2}{|c|}{$\begin{array}{l}\text { Waarvan effect op de individuele posten } \\
\text { is toegelicht }\end{array}$} \\
\hline & & 10 & $100 \%$ & 5 & $50 \%$ & 10 & $100 \%$ \\
\hline HBO & 16 & 15 & $94 \%$ & 9 & $56 \%$ & 12 & $75 \%$ \\
\hline MBO & 17 & 16 & $94 \%$ & 4 & $24 \%$ & 16 & $94 \%$ \\
\hline VO & 17 & 17 & $100 \%$ & 6 & $35 \%$ & 14 & $82 \%$ \\
\hline PO & 16 & 16 & $100 \%$ & 2 & $13 \%$ & 15 & $94 \%$ \\
\hline Totaal: & 76 & 74 & $97 \%$ & 26 & $34 \%$ & 67 & $88 \%$ \\
\hline
\end{tabular}

Uit deze nadere analyse blijkt dat in 26 (34 procent) jaarverslagen van de instellingen met een stelselwijziging is aangegeven welk gevolg dit heeft op het resultaat van het boekjaar. Voornamelijk het mbo, vo en po blijven hierin achter. Het effect op het vermogen ( 97 procent) en de individuele balansposten ( 88 procent) is wel in veel gevallen toegelicht. Van de 76 instellingen die aangeven dat een stelselwijziging heeft plaatsgevonden, lichten twee instellingen dit niet verder toe.

Opvallend is dat de plaats in het jaarverslag waar de stelselwijziging is toegelicht heel divers is. Dit komt zowel voor in het bestuursverslag, in de toelichting bij de waarderingsgrondslagen of als toelichting op het eigen vermogen. Ook de aangepaste vergelijkende cijfers over 2007 worden niet 
op eenduidige wijze gepresenteerd. Meestal wordt per post in de toelichting op de balans een verloopoverzicht opgenomen met de stand per 31 december 2007 en per 1 januari 2008. Veelal werden de vergelijkende cijfers over 2007 echter niet aangepast, maar de stelselwijziging als correctie op het eigen vermogen in het boekjaar doorgevoerd.

In figuur 2 is een best practice opgenomen met effect op resultaat en vermogen en op de vergelijkende cijfers.

\subsection{Consolidatie en segmentatie}

Op basis van artikel 3 sub h. van de Rjo zijn HO- en MBOinstellingen verplicht om per instelling en niet per rechtspersoon een apart jaarverslag op te stellen, omdat de desbetreffende onderwijswetten dat vereisen. Een andere optie voor de rapporterende eenheid, meer in lijn met het BW zou zijn geweest, de desbetreffende instellingen eerst 'proforma te consolideren' (RJ 660.5; RJ 217) binnen die ene rechtspersoon en vervolgens nadere informatie te verstrekken in het jaarverslag van die rechtspersoon op basis van segmentatie (RJ 660.308/403/610). Zie ook het volgende voorbeeld van het vraagstuk van de rapporterende eenheid in figuur 3 .

In RJ 660.308/610 staat aangegeven dat de staat van baten en lasten en de resultaatbestemming moeten worden gesegmenteerd indien de instelling activiteiten ontplooit in meerdere onderwijssectoren. In tabel 11 zijn de resultaten weergegeven met betrekking tot de segmentatie.

\section{Tabel 11 Aantal instellingen dat in meerdere onderwijs- sectoren actief is en aantal jaarverslagen met gesegmenteerde informatie}

\begin{tabular}{|l|l|c|r|c|c|}
\hline & \multicolumn{3}{|l|}{$\begin{array}{l}\text { Waarvan in } \\
\text { meerdere } \\
\text { Sector: }\end{array}$} & $\mathrm{n}:$ & \multicolumn{2}{l|}{$\begin{array}{l}\text { Waarvan } \\
\text { sectoren actief }\end{array}$} & \multicolumn{2}{l|}{$\begin{array}{l}\text { gesegmenteerde } \\
\text { informatie opgenomen }\end{array}$} \\
\hline WO & 14 & 4 & $21 \%$ & 4 & $100 \%$ \\
\hline HBO & 22 & 4 & $21 \%$ & 3 & $75 \%$ \\
\hline MBO & 22 & 8 & $42 \%$ & 3 & $38 \%$ \\
\hline VO & 20 & 3 & $16 \%$ & 2 & $67 \%$ \\
\hline PO & 18 & 0 & $0 \%$ & 0 & $0 \%$ \\
\hline Totaal: & 96 & 19 & $20 \%$ & 12 & $63 \%$ \\
\hline
\end{tabular}

Bij zeven instellingen ( 37 procent) is er niet voldoende gesegmenteerde informatie in de jaarverslagen opgenomen. Dit betrof voornamelijk MBO-instellingen waar ook onderwijs voor de VO-sector wordt gegeven.

\section{De financiële positie in de jaarrekening}

\subsection{Inleiding}

\section{Figuur 2 Best practice informatieverstrekking inzake stelselwijziging}

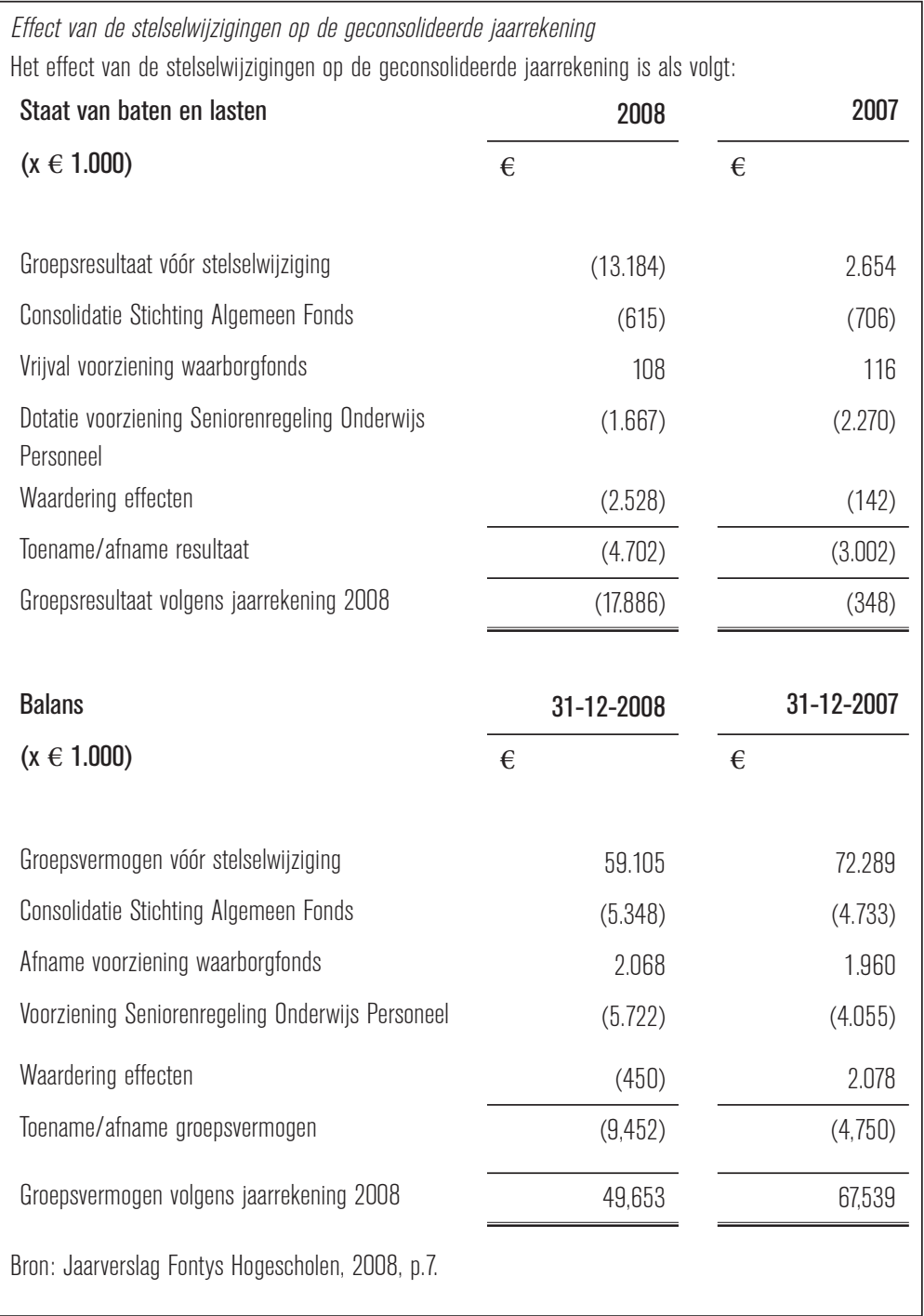

\section{Figuur 3 Voorbeeld: meerdere jaarverslagen binnen één rechtspersoon}

\section{De Vrije Universiteit, onderdeel van de Vereniging voor christelijk hoger onderwijs, wetenschappelijk} onderzoek en patiëntenzorg (kortweg: VU-Windesheim), brengt een eigen verslag uit. Dit uitgangspunt geldt eveneens voor de andere publieke lichamen binnen de Vereniging, te weten het VUmc en Hogeschool Windesheim

Bron: Jaarverslag Vrije Universiteit Amsterdam, 2008, p. 80.

De financiële positie van OZW's komt in belangrijke mate naar voren in de volgende balansposten: materiële vaste activa, liquide middelen, eigen vermogen en voorzieningen. Met uitzondering van de liquide middelen zijn deze belangrijkste balansposten nader geanalyseerd. Dat deze discussie (juist) ook op een PO-instelling speelt, blijkt uit het voorbeeld in figuur 4 . 


\section{Figuur 4 Best practice: Beoordeling financiële positie}

De school heeft een gezonde financiële positie wat onder andere wordt gereflecteerd in een weerstandsvermogen (algemene reserves/totale structurele baten) van ruim 19\%. Door het VBS en PricewaterhouseCoopers wordt kleine scholen aanbevolen een weerstandsvermogen aan te houden van ongeveer 15\%. Verder heeft de directie een risicoanalyse gedaan die de toereikendheid van de algemene reserves bevestigt.

Bron: Jaarrekening St. Katholieke School Oegstgeest, 2008, p. 7.

\subsection{Materiële vaste activa, in het bijzonder gebouwen}

De mogelijkheden voor de toepassing van waarderingsgrondslagen voor de instellingen zijn verruimd: in plaats van historische kosten, is ook waardering op actuele waarde toegestaan. Omdat dit voornamelijk op gebouwen en terreinen van toepassing is, heeft dit onderzoek zich tot deze categorie activa beperkt. Daarnaast heeft de overdracht van de gebouwen van OCW per onderwijssector in verschillende jaren plaatsgevonden en is dit ook verschillend uitgevoerd. Het grote verschil tussen de mate waarin het $\mathrm{WO}, \mathrm{HBO}$ en $\mathrm{MBO}$ enerzijds en het VO en PO anderzijds in gebouwen en terreinen investeren, is te verklaren door de verantwoordelijkheid voor huisvesting die bij de laatste twee sectoren niet primair bij de instelling ligt, maar bij de gemeente. De instelling bezit wel het juridisch eigendom, maar in principe niet het economisch eigendom. Hierbij is het opvallend dat deze twee sectoren in het afgelopen jaar relatief meer in gebouwen en terreinen hebben geïnvesteerd. Dit terwijl de wetgeving aangeeft dat de huisvesting voor vo en po door de gemeente moet worden bekostigd en PO-schoolbesturen formeel de onderwijsbekostiging niet mogen aanwenden voor aanvullende huisvestingsvoorzieningen. Uit een nadere analyse blijkt dat er nauwelijks instellingen in het $\mathrm{VO}$ en $\mathrm{PO}$ zijn die in de waarderingsgrondslagen of toelichting op de materiële vaste activa aangeven waaruit de post gebouwen en terreinen bestaat en of het bevoegd gezag juridisch eigenaar is van de (overige) gebouwen waarin de instelling gehuisvest is.

Voor de instellingen is het vanaf 2008 onder andere moge- lijk om de componentenmethode (RJ 212.418) toe te passen, waarbij belangrijke bestanddelen van een vast actief afzonderlijk worden afgeschreven. In tabel 12 is opgenomen in hoeverre deze methode in 2008 werd toegepast.

\section{Tabel 12 Aantal instellingen dat de componentenmethode toepast bij waardering van gebouwen}

\begin{tabular}{|l|l|c|c|}
\hline Sector: & n: & \multicolumn{2}{|c|}{$\begin{array}{c}\text { Gomponentenmethode toegepast bij } \\
\text { waardering gehouwen }\end{array}$} \\
\hline WO & 14 & 9 & $64 \%$ \\
\hline HBO & 22 & 5 & $23 \%$ \\
\hline MBO & 22 & 4 & $18 \%$ \\
\hline VO & 20 & 0 & $0 \%$ \\
\hline P0 & 18 & 0 & $0 \%$ \\
\hline Totaal: & 96 & 18 & $19 \%$ \\
\hline
\end{tabular}

De componentenmethode wordt door 18 (19 procent) van de instellingen toegepast. Van de onderzochte instellingen in het w.o., hbo en mbo past 31 procent de componentenmethode volledig toe. Opvallend is dat twee instellingen in het w.o. en vijf in het hbo de componentenmethode maar voor een gedeelte van de activa toepassen. Eén instelling past deze methode alleen toe voor investeringen na 2007. De overige zes instellingen leggen de scheidslijn bij het boekjaar 2000 . Investeringen na dit jaar worden volgens de componentenmethode afgeschreven. Daarvoor werd nog op het gehele pand als één geheel afgeschreven. Deze scheidslijn kwam voor in de oude OCW-richtlijn. Mede in verband met de praktische uitvoerbaarheid worden blijkbaar meerdere soorten of categorieën van gebouwen onderkend (RJ 110.124; RJ 212.446). Naast de waardering tegen kostprijs is het vanaf 2008 toegestaan om de gebouwen op actuele waarde te waarderen (RJ 212.301/401). De actuele waarde moet sowieso in de toelichting op de balans worden vermeld (RJ 212.707). In tabel 13 is aangegeven hoe de instellingen in de steekproef hiermee om zijn gegaan.

\section{Tabel 13 Aantal instellingen dat de gebouwen op actuele waarde waardeert en de mate waarin de actuele waarde in de toelichting is opgenomen}

\begin{tabular}{|c|c|c|c|c|c|c|}
\hline \multirow{2}{*}{$\begin{array}{l}\text { Sector: } \\
\text { WO }\end{array}$} & \multirow{2}{*}{ n: } & \multicolumn{2}{|c|}{$\begin{array}{l}\text { Aantal instellingen met waardering } \\
\text { gebouwen op actuele waarde }\end{array}$} & \multirow{2}{*}{$\begin{array}{l}\text { Aantal instellingen met gebouwen op } \\
\text { historische kosten } \\
\qquad 14\end{array}$} & \multicolumn{2}{|c|}{$\begin{array}{l}\text { Aantal instellingen met gebouwen die de actuele } \\
\text { waarde in de toelichting hebben vermeld }\end{array}$} \\
\hline & & 0 & $0 \%$ & & 11 & $79 \%$ \\
\hline HBO & 22 & 1 & $5 \%$ & 21 & 13 & $62 \%$ \\
\hline MBO & 22 & 0 & $0 \%$ & 17 & 11 & $65 \%$ \\
\hline VO & 20 & 1 & $5 \%$ & 17 & 12 & $71 \%$ \\
\hline PO & 18 & 0 & $0 \%$ & 1 & 0 & \\
\hline Totaal: & 96 & 2 & $2 \%$ & 70 & 47 & $67 \%$ \\
\hline
\end{tabular}




\section{Figuur 5 Best practice materiële vaste activa}

\author{
Gebouwen en terreinen \\ De gebouwen, waaronder begrepen vaste installaties, worden gewaardeerd tegen aanschaffingswaarde, \\ verminderd met afschrijvingen. \\ Met ingang van 1 januari 2004 wordt op nieuwe investeringen afgeschreven volgens de \\ componentenmethode. Bij deze methode wordt het casco in 60 jaar afgeschreven, de afbouw en \\ infrastructuur in 30 jaar en de overige installaties en inrichtingskosten in 15 jaar. \\ Bij de afschrijvingen van gebouwen die tussen 2000 en 2004 in gebruik zijn genomen, wordt uitgegaan \\ van een afschrijvingspercentage van 4.00\%, behoudens voor die gebouwen waarvan de levensduur op \\ bedrijfseconomische gronden korter is dan 25 jaar en derhalve een hoger percentage gewenst is. \\ De afschrijvingen van gebouwen die vóór 2000 in gebruik zijn genomen, bedragen lineair 3.33\% per jaar \\ berekend over de aanschaffingswaarde. \\ De terreinen zijn gewaardeerd tegen aanschaffingswaarde. Hierop wordt niet afgeschreven. \\ Bron: Jaarverslag TU Eindhoven, 2008, p. 81.
}

In totaal hebben twee instellingen gebruik gemaakt van de mogelijkheid om de gebouwen tegen actuele waarde te waarderen. Beide instellingen passen deze grondslag niet voor alle gebouwen toe. Eén instelling heeft namelijk één pand op actuele waarde en de overige op historische kostprijs gewaardeerd. De andere instelling past deze waardering niet voor alle gebouwen en terreinen toe. Ook hier worden blijkbaar meerdere soorten of categorieën van gebouwen onderkend (RJ 110.124; RJ 212.401). Informatie over de actuele waarde in de toelichting (RJ 212.707) wordt door $47(67 \%)$ instellingen opgenomen omdat de gebouwen zijn gewaardeerd op historische kosten, wat volgens het ministerie ook belangrijk is voor de uniformiteit (zie ook OCW, 2009c, p. 22). Het toelichten van belangrijke afwijkingen tussen de boekwaarde en de actuele waarde van de activa gebeurt niet door 51 (73\%) van de 70 instellingen, maar is ook niet verplicht. Een goed voorbeeld van de toelichting op de afschrijvingen is opgenomen in figuur 5.

\subsection{Eigen vermogen}

Mede gezien het hybride karakter van onderwijsinstellingen is het van belang dat de instellingen een splitsing

\section{Tabel 14 Aantal jaarverslagen waarin een splitsing van het eigen vermogen is opgenomen naar fondsen - reserves en privaat - publiek}

\begin{tabular}{|c|c|c|c|c|c|c|c|}
\hline \multirow{2}{*}{$\frac{\text { Sector: }}{\text { WO }}$} & \multirow{2}{*}{$\frac{n:}{14}$} & \multicolumn{2}{|c|}{$\begin{array}{l}\text { Splitsing naar } \\
\text { fondsen en } \\
\text { reserves aanwezig }\end{array}$} & \multicolumn{2}{|c|}{$\begin{array}{l}\text { Splitsing naar privaat } \\
\text { en publiek aanwezig }\end{array}$} & \multicolumn{2}{|c|}{$\begin{array}{l}\text { Toelichting private } \\
\text { activiteiten } \\
\text { opgenomen }\end{array}$} \\
\hline & & 12 & $86 \%$ & 7 & $50 \%$ & 4 & $57 \%$ \\
\hline HBO & 22 & 16 & $73 \%$ & 15 & $68 \%$ & 11 & $73 \%$ \\
\hline MBO & 22 & 10 & $45 \%$ & 7 & $32 \%$ & 2 & $29 \%$ \\
\hline Vo & 20 & 15 & $75 \%$ & 16 & $80 \%$ & 8 & $50 \%$ \\
\hline PO & 18 & 15 & $83 \%$ & 14 & $78 \%$ & 4 & $29 \%$ \\
\hline Totaal: & 96 & 68 & $71 \%$ & 59 & $61 \%$ & 29 & $49 \%$ \\
\hline
\end{tabular}

aanbrengen in het eigen vermogen naar zowel publiek ${ }^{6}$ en privaat (RJ 660.206 en RJ 940) als naar bestemmingfonds (RJ 660.207; beperking besteding door derden) en reserves (RJ 660.208; beperking besteding door bestuur). Dit is in tabel 14 weergegeven.

Van de instellingen hebben 68 ( 71 procent) dit jaar een splitsing in het eigen vermogen opgenomen naar bestemmingsfondsen en -reserves. Opvallend is dat voornamelijk het mbo hierin achterblijft. Uit een nadere analyse blijkt dat negen van deze instellingen aangeven dat het onderscheid in 2009 zal worden aangebracht. Voor deze aanduiding gebruiken MBO-instellingen dezelfde zinsnede, waarin wordt aangegeven dat gezien het belang van deze splitsing het zorgvuldig moet gebeuren.

Ook bij de splitsing naar private en publieke reserves blijft het $\mathrm{MBO}$ om dezelfde reden, achter. Opvallend is hierbij ook dat juist de sectoren die het meeste private activiteiten ontplooien (WO en $\mathrm{HBO}$ ) achterblijven bij het aanbrengen van de splitsing ten opzichte van de sectoren VO en PO. Ongeveer de helft van de instellingen besteedt in haar jaarverslagen aandacht aan de aard van de private activiteiten. De HO-instellingen scoren hier juist beter op. Een goed voorbeeld van de toelichting op de private reserve is opgenomen in figuur 6 .

\section{Figuur 6 Best practice informatieverstrekking inzake eigen vermogen}

\section{Bestemmingsreserve Privaat}

Met ingang van het boekjaar 2008 wordt onderscheid gemaakt tussen het publieke en het private deel van het vermogen. Op basis van de omschrijving RJ 660 kan worden geconcludeerd dat ontvangen bijdragen die ontvangen zijn vanuit de rijksbegroting publieke middelen zijn. Dat geldt ook voor ontvangen middelen inzake wettelijk cursus/collegegeld. Alle overige ontvangsten kunnen derhalve als privaat worden beschouwd. Over het private vermogen mag door de instelling vrijelijk binnen de statutaire bepalingen worden beschikt.

Bron: Jaarrekening IPABO Amsterdam, 2008, p. 54.

\subsection{Voorzieningen}

In het kader van dit onderzoek is bij de instellingen aandacht besteed in hoeverre voorzieningen zijn getroffen voor groot onderhoud gebouwen (RJ 212.445/446) en voor de regeling Bevordering ArbeidsParticipatie Ouderen (BAPO; RJ 271.203). Deze laatste is alleen van belang bij de sectoren mbo, vo en po.

In totaal hebben 44 ( 46 procent) van de onderzochte instellingen een voorziening voor groot onderhoud. Een deel van de 52 instellingen die geen voorziening voor groot onderhoud heeft getroffen, volgt de componenten- 
Tabel 15 Voorzieningen voor groot onderhoud en BAPO

\begin{tabular}{|l|c|c|c|c|c|}
\hline Sector: & $\mathbf{n}:$ & \multicolumn{2}{|c|}{$\begin{array}{l}\text { Voorziening voor groot } \\
\text { onderhoud opgenomen }\end{array}$} & \multicolumn{2}{c|}{$\begin{array}{c}\text { Voorziening voor } \\
\text { BAPO opgenomen }\end{array}$} \\
\hline WO & 14 & 2 & $14 \%$ & Nvt & Nvt \\
\hline HBO & 22 & 8 & $36 \%$ & Nvt & Nvt \\
\hline MBO & 22 & 9 & $41 \%$ & 17 & $77 \%$ \\
\hline VO & 20 & 13 & $65 \%$ & 17 & $85 \%$ \\
\hline PO & 18 & 12 & $67 \%$ & 16 & $89 \%$ \\
\hline Totaal: & 96 & 44 & $46 \%$ & 50 & $83 \%$ \\
\hline
\end{tabular}

methode (zie paragraaf 6.2). Opmerkelijk is dat vier instellingen zowel de componentenmethode als een voorziening voor groot onderhoud toepassen. Dit zijn instellingen die maar gedeeltelijk zijn overgegaan op de componentenmethode. Zoals eerder aangegeven worden mede in verband met de praktische uitvoerbaarheid blijkbaar meerdere soorten of categorieën van gebouwen onderkend (RJ 110.124; RJ 212.446). De instellingen in het WO en HBO passen de componentenmethode meer toe.

Van de onderzochte instellingen in het mbo, vo en po hebben 50 ( 83 procent) een voorziening voor BAPO-rechten opgenomen in de jaarrekening. Dit zou een voorziening voor opgespaarde, nog niet opgenomen BAPO-rechten moeten zijn, op basis van de systematiek van voor 2008 (art. za sub a Rjo; vergelijkbaar met niet opgenomen vakantiedagen). Dit blijkt echter niet altijd duidelijk uit de jaarrekening. In paragraaf 6.5 wordt hierop nader ingegaan.

Uit de jaarrekeningen blijkt dat 49 (51 procent) van de instellingen alle personeelsvoorzieningen waardeert op contante waarde (RJ 271.207). Bij de andere instellingen blijkt dit niet uit de jaarrekening of wordt aangegeven dat gewaardeerd wordt tegen nominale waarde. Opvallend is dat slechts twee instellingen in het vo de voorzieningen op contante waarde waarderen.

Opgevallen is dat de aard van de opgenomen voorzieningen bij de HO-instellingen sterk verschilt. Voorzieningen voor het waarborgfonds en Seniorenregeling onderwijspersoneel (SOP) worden bij de ene instelling afgewaardeerd naar nihil, terwijl een andere instelling deze nog heeft opgenomen. Dit komt de vergelijkbaarheid niet ten goede (zie ook OCW, 2009c, p. 23).

\subsection{BAPO-voorziening nader beschouwd}

Het mogelijk effect van de Bevordering ArbeidsParticipatie Ouderen (BAPO) r regeling, een beloning met opbouw van rechten, op de jaarverslaggeving, heeft begin 2009 bij het opstellen van de jaarrekening 2008 grote commotie binnen de onderwijssector en bij de minister veroorzaakt. Mogelijk zou het eigen vermogen van de sector negatief worden. Het heeft geleid tot brieven (OCW, 2009a), krantenberichten (NRC, 2009), daarop gebaseerde Kamervragen (Tweede Kamer, 2009), een aangepaste Rjo (OCW, 2009b) en artikelen in tijdschriften (Litjens, 2009; Dekker, 2009; Vergoossen, 2009).

De vaktechnische en/of politiek bestuurlijke vraag is of geen voorziening maar 'duur personeel' obv RJ 271.202/204 en hoe voor deze BAPO-rechten een (bruto)voorziening op basis van RJ 271.203 of RJ 271.402 gevormd dient te worden en of een bepaald gedeelte van de, na de balansdatum te ontvangen bekostiging van OCW, op basis van RJ 252.311 daarop wel of niet in mindering gebracht mag worden (nettovoorziening). Hierbij speelt ook de eventuele eigenheid van de sector een rol en welke mogelijke verslaggevingsoptie voldoet aan het wettelijk vereiste inzicht (art. 2:362 lid $1 \mathrm{BW}$ ), gegeven de derogatiebepaling (art. 2:362 lid 4 BW).

De VO- en PO-sectoren zijn door deze commotie voor 2008 en 2009 vrijgesteld van het treffen van de RJ 271-voorziening in de jaarrekening als die nog niet aanwezig was op basis van de oude systematiek. De minister van Onderwijs heeft dit geregeld via een brief aan de sector po en vo (OCW, 2009a) en de aanpassing van de regeling (OCW, 2009b). Daarin wordt wel een bijlage (art. 3a sub b Rjo) voorgeschreven, waarin de benodigde informatie op basis van RJ 271 dient te worden opgenomen. Deze discussie zou vóór het verslagjaar 2010 opgelost moeten zijn. In die bijlage bij de jaarrekening (art. za sub b Rjo) dient inzicht gegeven te worden in de hoogte van de noodzakelijke BAPOvoorziening. Dit betreft een voorziening voor opbouw van rechten (RJ 271.203), terwijl de voorziening in de balans (zie de paragraaf 6.4) betrekking heeft op de opgespaarde rechten. De onderzochte jaarverslagen zijn hierover niet altijd even transparant.

In tabel 16 zijn de resultaten uit het onderzoek weergegeven naar het opnemen van deze informatie in bijlage weergegeven.

Twee vo-instellingen hebben niet aan de verplichting tot het opnemen van deze informatie in de bijlage voldaan. De

\section{Tabel 16 Aantal jaarverslagen waarin de bijlage BAPO is opgenomen}

\begin{tabular}{|c|c|c|c|c|}
\hline \multirow{2}{*}{$\begin{array}{l}\text { Sector: } \\
\text { VO }\end{array}$} & \multirow{2}{*}{$\frac{n:}{20}$} & \multicolumn{2}{|c|}{ Bfflage opgenomen } & \multirow{2}{*}{$\begin{array}{l}\text { Waarvan voorziening } \\
\text { noodzakelfjk } \\
11\end{array}$} \\
\hline & & 18 & $90 \%$ & \\
\hline PO & 18 & 18 & $100 \%$ & 10 \\
\hline Totaal: & 38 & 36 & $95 \%$ & 22 \\
\hline
\end{tabular}

overige 36 (95 procent) instellingen uit het vo en po doen dit wel.

\section{Samenvatting, conclusies en aanbevelingen}

De onderwijssector heeft een belangrijke stap naar verdere harmonisatie van regelgeving gezet met de invoering van de eerste Richtlijn voor onderwijsinstellingen, RJ 660. Het 
merendeel van de instellingen lijkt op hoofdlijnen adequaat met de implementatie van RJ 660 omgegaan te zijn. Maar transparantie en uniformering vragen om verdere stappen, zowel wat betreft de financiële als nietfinanciële informatie in het jaarverslag. De overheid geeft niet duidelijk aan wat ze eigenlijk wil met de openbaarheid van de jaarverslagen van de onderwijssector. Dit afgezet tegen het gegeven dat het ministerie de horizontale verantwoording naar direct betrokkenen over onderwijsinstellingen zo belangrijk vindt. Geconstateerd is dat het verslag van de Raad van Toezicht in in de niet HO- jaarverslagen ontbreekt. Ook de informatie over de doelgerichtheid van de organisatie, de verantwoording over de realisatie en streefwaarden en over de interne beheersing laten in de onderzochte jaarverslagen te wensen over.

In geen van de onderzochte jaarverslagen wordt aangegeven dat de instelling in control is. Dat geldt ook voor de verantwoording over de rechtmatigheid. Wel wordt in verschillende jaarverslagen vermeld dat gewerkt wordt aan de ontwikkeling van de interne risicobeheers- en controlesysteem en de verantwoording daarover. Horizontale verantwoording en het verstrekken van gesegmenteerde informatie, in het bijzonder in het $\mathrm{MBO}$, kunnen worden verbeterd. De informatie over de stelselwijziging wat betreft het effect op het resultaat en de vergelijkende cijfers over 2007 laten in de onderzochte jaarverslagen te wensen over, vooral in het $\mathrm{MBO}$, $\mathrm{VO}$ en $\mathrm{PO}$. Het ministerie zou nog eens moeten kijken naar de uniformiteit van de rapporterende eenheid (instelling of rechtspersoon) in de verschillende onderwijssectoren. Hierbij zou aangesloten dienen te worden bij de opzet van het BW: een keuze voor de rechtspersoon als rapporterende eenheid. Ook het verstrekken van gesegmenteerde informatie in het bijzonder in het mbo, zou kunnen worden verbeterd.

De financiële positie van onderwijsinstellingen staat in de politieke belangstelling. De verschillende eigendomsver- houdingen van de gebouwen per onderwijssector en de nog weinig uniforme en transparante waardering van die gebouwen binnen en tussen instellingen vormen hierbij een complicerende factor. Het gaat met name om de waardering tegen actuele waarde, het gebruik van de componentenmethode en de voorziening voor groot onderhoud. De splitsing van het eigen vermogen naar private en publieke reserves en de toelichting daarop blijft bij het mbo achter ten opzichte van de andere sectoren. De eventuele BAPO-voorziening blijft zorgen voor nog niet opgeloste principiële discussies.

Uit dit onderzoek en het rapport van de commissie-Don (OCW, 2009c) blijkt een opdracht aan de onderwijssector en de koepelorganisaties van besturen uit die sectoren om gezamenlijk de kwaliteit van het financieel management en de jaarverslagen te verbeteren. Hieraan zou nader onderzoek en een rapportage van het ministerie over best practices in vooral het $\mathrm{PO}$ en $\mathrm{VO}$ een belangrijke bijdrage kunnen leveren.

Drs. P.J.J. Vos RA is coördinator publieke sector bij het Koninklijk NIVRA. Tevens is hij lid van de RJ-werkgroep Onderwijs en lid van de MR van een VO-school.

Prof. dr. J.M. J. Blommaert is hoogleraar aan de Universiteit van Tilburg/TiasNimbas Business School en de Universiteit Leiden. Tevens is hij verbonden aan Bureau Vaktechniek van BDO-accountants en -adviseurs en lid van de vaktechnische staf van de Raad voor de Jaarverslaggeving.

$\mathrm{J}$. Berkouwer is student aan de Nyenrode School of

Accountancy \& Controlling en werkzaam bij Van Ree

Accountants. Tevens is hij bezig met zijn scriptie over de invoering van RJ 660.

Deze bijdrage is geschreven op persoonlijke titel.

\section{Literatuur}

- Aukes, J. (1996), Externe verslaggeving door non-profit organisaties, 3e druk, Groningen: Wolters-Noordhoff.

Dees, M., G.T. Budding, F.D.J. van Schaik, T.A. van Tiel (2009), Externe verslaggeving van publieke organisaties, Den Haag: Sdu uitgevers. - Dekker, G. (2009), Mooi weer als het regent. Verslaggevingsstandaarden op politieke agenda De Accountant, 2009, nr. 10, oktober, p. 24-29. - Herremans, J.H.H.M., E.A.M. Mentink, M.N. Hoogendoorn (2003), Verslaggeving van organisaties zonder winstoogmerk: een normatief raamwerk, 2e druk, Deventer/ Amsterdam: Kluwer/Limperg Instituut.
- Litjens, R. (2009), Hoe ziet dat 'geknoei' in de jaarrekening 2008 er nou uit?, Accountancynieuws, nr. 16, 28 augustus, p. 16-18.

- NRC Handelsblad (2009), Plasterk: 'knoeien' met balans mag, School laat liever wat rijkdom zien, 18 maart, p. 1 en 3

- OCW, Minister van (2007), Regeling jaarverslaggeving onderwijs (Rjo), Regeling van 17 december 2007, nr. WJZ/2007/50507, houdende nadere voorschriften voor de inrichting van de jaarverslaggeving van door de minister van Onderwijs, Cultuur en Wetenschap dan wel de minister van Landbouw, Natuur en
Voedselkwaliteit bekostigde

onderwijsinstellingen.

- OCW, ministerie van (2008), Richtlijn Jaarverslag Onderwijs, Toelichtende brochure, februari 2008

- OCW, minister van (2009a), BAPOvoorziening, Brief van 26 februari 2009 (AD/104458) aan het bestuur van alle door het ministerie van OCW bekostigde instellingen in de sectoren po en vo.

- OCW, minister van (2009b), Wijziging van de Regeling jaarverslaggeving onderwijs, Regeling van 28 april 2009, nr. VO/FBI/2009/107875. 口0CW, minister van (2009c), Aanbieding 
rapport commissie Vermogensbeheer onderwijsinstellingen, Brief van 4 november 2009 (FEZ/CPC/CC/154421) aan de Tweede Kamer der Staten Generaal, Kamerstuk 32123 VIII, nr. 30

- Raad voor de Jaarverslaggeving (2009),

Richtlijnen voor de jaarverslaggeving voor grote en middelgrote rechtspersonen, RJ 660: Onderwijsinstellingen, jaareditie 2009, Deventer/ Amsterdam: Kluwer/RJ.

- Tweede Kamer der Staten-Generaal (2009), Vragen over creatief boekhouden van scholen, Aanhangsel van de Handelingen nr. 2570, 14 april.
Vergoossen, R.G.A (2009), Raad voor de Jaarverslaggeving: de tijd van gaan is gekomen!, Maandblad voor Accountancy en Bedrijfseconomie, jg. 83, nr. 11, november, pp. 334-336.

Bijlage: Onderzochte jaarverslagen 2008 van onderwijsinstellingen

Universiteiten (bevoegd gezag en nummer):

1. Rijks Universiteit Groningen (00008)

2. Universiteit Utrecht (00009)

3. Erasmus Universiteit R'dam (0oo10)

4. Techn. Universiteit Delft (00011)

5. Techn. Universiteit Eindhoven (00012)

6. Universiteit Twente (00013)

7. Wageningen Universiteit (ooo14)

8. Universiteit Leiden (0o039)

9. Radboud Universiteit Nijmegen (20280)

10. Vrije Universiteit Amsterdam (22222)

11. Universiteit van Tilburg (30720)

12. Open Universiteit (75571)

13. Universiteit van Amsterdam (75792)

14. Universiteit Maastricht (75805)

\section{HBO-instellingen (bevoegd gezag en} nummer):

1. Codarts (24832)

2. HS voor kunsten Utrecht (28901)

3. Katholieke PABO Zwolle (30041)

4. Avans Hogescholen (30183)

5. Hogeschool Rotterdam (30299)

6. IPABO Amsterdam/Alkmaar (30327)

7. NHTV Breda (30332)

8. Saxion Hogescholen (30780)

9. Hanzehogeschool Groningen (40169)

10. HAS Den Bosch (40205)

11. Chr. Hogeschool Ede (40235)

12. Hogeschool Utrecht (40516)

13. Hogeschool Edith Stein (40846)

14. Stichting ArtEZ (41292)

15. HBO Haaglanden en Rijnstreek (41378)

16. Hogeschool Drenthe (41554)

17. IJsselgroep Iselinge HS (41618)
18. Pedagogische Hogeschool de Kempel (50338)

19. Fontys Hogescholen (60126)

20. Hotelschool Den Haag (60763)

21. Marnix Academie (72230)

22. Hogeschool Arnhem/Nijmegen (72243)

\section{MBO-instellingen (bevoegd gezag en} nummer):

1. Stichting Hout en Meubel KBB (30740)

2. Stichting Onderwijsgroep Tilburg (31087)

3. Stichting Grásch Lyceum Utrecht (31121)

4. STC-Group (31127)

5. ROC Ter AA (31150)

6. Stichting SOMA-College (34386)

7. ROC Rivor (40190)

8. ROC Friesland College (40295)

9. Stichting Savantis (40483)

10. Stichting AOC Clusius College (40673)

11. Stichting Aeres Groep (40687)

12. Midwest Groep (40800)

13. ROC van Amsterdam (40833)

14. Deltion College (40844)

15. ROC Leiden (40855)

16. AOC Oost (40979)

17. ROC onderwijsgroep A12 (41300)

18. ROC van Twente (41462)

19. Katholieke Stichting Bev.

Beroepsonderwijs (54484)

20. Stichting Nimeto (67991)

21. Lift Group (68277)

22. Stichting VAPRO (68719)

\section{Vo-instellingen (bevoegd gezag en} nummer):

1. BC Scholengroep Cambium (13358)

2. Com. Openbare Brede SGM Leiden
(13544)

3. Stichting OSG Piter Jelles (13603)

4. CVO Alblasserwaard west (30783)

5. Stichting VMO Nijmegen e.o. (40375)

6. Vereniging Chr. VO in Leiden e.o. (40623)

7. Stichting VO Amsterdam Zuid (40776)

8. ASOJ Voorhout (41008)

9. Stichting Vrije Scholen ZW-Ned. (41220)

10. Stichting Agnieten College de Boog (41430)

11. Stichting J. de Witt-gymnasium (41513)

12. Stichting Magical Education (41592)

13. Stichting Dunamare (41664)

14. Het Stedelijk Lyceum (41804)

15. Stichting Fioretti Teylingen (53990)

16. Stichting Petrus Canisius College (71436)

17. Stichting VO Sliedrecht e.o. (74713)

18. Stichting RK VHMO Noord-R'dam (78482)

19. Aloysiusstichting (82799)

20. Vereniging KAVOR Rotterdam (99542)

Het jaarverslag van de Stichting Katholiek VO Breda e.o. (42992) was nog niet ontvangen.

PO-instellingen (bevoegd gezag en nummer):

1. Gem Noordenveld (11711)

2. REC oost Nederland SWV (20862)

3. Vereniging tot verstr $\mathrm{BSO}$ Kruiningen (29473)

4. Stichting bijzonder onderwijs algemeen Middelburg (30715)

5. Delftse Vereniging Montessori (31162) 
6. Vereniging Onderwijs Wilhelm School Doetinchem (36349)

7. Chrisophorus Emmeloord (40662)

8. VPCO Dalfsen (40998)

9. Veendam SWV (41110)

10. Stichting de vier Windstreken (41194)

11. CPOB Betuwe (41424)
12. Stichting Katholiek Basisonderwijs Sivolde (41563)

13. Stichting OBSG Leiderdorp (41675)

14. Vereniging Christelijk PO

Spijkenisse (45917)

15. Stichting katholiek Onderwijs Achterveld (65768)

16. Stichting katholieke school
Oegstgeest (75206)

17. Verstrekking onderwijs op GG Grf

Gemeente (81902)

18. Vereniging stichting instandhouding school met de bijbel

Schuinesloot (91079)

De jaarverslagen van WSNS Hoeksche Waard (20655), Vereniging van Protestants Christelijk Basisonderwijs (24078) en Vereniging Algemeen Bijzonder Onderwijs (86269) waren nog niet ontvangen.

\section{Noten}

1 Het MBO is een onderdeel van de sector Beroepsonderwijs en Volwasseneneducatie (BVE).

2 In de onderwijssector en -regelgeving wordt ook wel gesproken over 'bestuur' of 'bevoegd gezag' als de rechtspersoon wordt bedoeld.

2 De HBO-Raad heeft een webpagina waarop links zijn opgenomen naar de webpagina's met de jaarverslagen van de afzonderlijke hbo-instellingen.

4! De ontwikkelingen bij woningcorporaties is dat de jaarrekeningcontrole wel een wettelijke controle wordt zoals bedoeld in de Wta en de jaarrekening dan bedoeld is voor het maatschappelijk verkeer. 5 De aantallen besturen in tabel 1 en 2 komen niet overeen, omdat gebruik gemaakt is van verschillende bronnen en tijdstippen. Ook consistentie van begrippen is hierbij een probleem. 6 Gelden verkregen ten laste van de rijksbegroting of anderszins uit hoofde van bij of krachtens de wet- en regelgeving verkregen gelden, alsmede de opbrengsten daarvan, waarover een instelling de beschikking heeft gekregen om haar (wettelijke) taak te verrichten.

$7 \mathrm{De}$ BAPO-regeling is een regeling op basis waarvan werknemers vanaf een bepaalde leeftijd ervoor kunnen opteren om tegen inlevering van een gering deel van het salaris aanvullend verlof te verkrijgen. 